Соколова О.М.

кандидат економічних наук, доцент

Університет державної фіскальної служби Украӥни ORCID: https://orcid.org/0000-0002-7061-3692

\title{
РОЛЬ ТЕХНОЛОГІЧНОЇ СТРУКТУРИ ПЕРЕРОБНОЇ ПРОМИСЛОВОСТІ У ЗАБЕЗПЕЧЕННІ ІННОВАЦІЙНОӤ МОДЕЛІ РОЗВИТКУ ЕКОНОМІКИ УКРАЇНИ
}

У статті обтрунтовано особливу роль переробної промисловості у забезпеченні інновачійної моделі начіональної економіки. Доведено, щу реалізація інноваційної стратегії висуває особливі вимоги до промисловості, їі адекватності науково-технічним досягненням постіндустріального суспільства. Визначено, шо якісною характеристикою переробної промисловості є ї̈ технологічна структура. Здійснено аналіз чотирьох секторів технологічної структури переробної промисловості за рівнем технологічності. Проаналізовано структурні складники чотирьох секторів переробної промисловості за видами економічної діяльності згідно з класифікацією Свростату. Установлено, щчо причиною відставання технологічного розвитку України є ї̈ інституиійна неспроможність. Запропоновано створення профільного вищого органу державного управління інновачійним розвитком промисловості.

Ключові слова: технологічна структура, промисловість, переробна промисловість, високотехнологічне виробництво, інноваційна модель розвитку.

Постановка проблеми. У забезпеченні інноваційної моделі економічного розвитку вирішальну роль відіграє промисловість. Розвиток промислового виробництва більше за інші сектори впливає на ринок праці та глобальну конкурентоспроможність країни. Сучасна промисловість, особливо ії високотехнологічний сектор, $є$ генератором науково-технічного прогресу та інновацій в економіці. Технології $є$ запорукою розвитку та прогресу кожного окремого підприємства, галузі й усієї національної економіки. Саме тому високотехнологічність стає розповсюдженим і провідним показником розвитку та місця економічних суб'єктів у міжнародних економічних відносинах. Серед найбільш впливових та водночас проблемних ланок промисловості України технологічна структура переробної промисловості.

Аналіз останніх досліджень і публікацій. Дослідженню різних аспектів інноваційної діяльності в контексті формування передумов забезпечення конку- рентних позицій національної економіки присвячено праці відомих українських учених, зокрема Ю. Бажала, В. Бодрова, О. Власюка, М. Гамана, В. Геєця, В. Осецького, В. Семиноженка, Л. Федулової та ін. На проблемах інноваційно-технологічного розвитку промисловості, високотехнологічного виробництва, стимулювання технологічних інновацій у промисловість акцентують увагу такі економісти, як С. Іщук, Ю. Кіндзерський, I. Одотюк, О. Саліхова, Н. Шелудько та ін.

Незважаючи на вагомий внесок учених у питання інноваційного розвитку національного господарства, модернізації та технологічного оновлення промисловості, дослідження технологічної структури переробної промисловості в контексті забезпечення інноваційної моделі розвитку економіки України, потребують подальших наукових розвідок.

Мета статті полягає в аналізі сучасного стану технологічної структури переробної промисловості Укра- 
їни та обгрунтуванні її ролі у забезпеченні інноваційної моделі розвитку економіки України, виробленні практичних рекомендацій.

Виклад основного матеріалу. Сталий соціальноекономічний розвиток країни можливий тільки в рамках інноваційної моделі, характерними рисами якої є перенесення акценту на використання принципово нових прогресивних технологій, перехід до випуску високотехнологічної продукції, прогресивні організаційні та управлінські рішення в усіх сферах господарської діяльності. Інноваційний шлях розвитку визначає стійкість національної економіки, іиї конкурентоспроможність та формує реальні конкурентні переваги країни на світовому ринку.

Інноваційна модель розвитку - це забезпечення прогресивних структурних зрушень в економіці країни та підвищення іiі технологічного рівня. Країни світу, які перейшли на інноваційну модель, здійснили технологічний прорив і перетворилися на світових лідерів. Їхні економіки характеризуються високотехнологічним типом національного виробництва, а новітні технології тією чи іншою мірою пронизують усі види економічної діяльності. Інноваційна спроможність економіки визначається можливістю поширювати в усіх сферах нові продукти та технології, завойовувати відповідні ринки. Сприйнятливість національного господарства до інновацій залежить також від технологічної структури економіки, рівня науково-технічного і виробничого потенціалу, ступеня відповідності інституціональної структури тощо.

Реалізація інноваційної моделі висуває особливі вимоги до промисловості, яка $є$ найбільш активним чинником науково-технічного прогресу та визначальним системоутворюючим механізмом підвищення конкурентоспроможності національної економіки. Підтвердженням цього $є$ настанови Лімської декларації 15-ї Генеральної конференції ЮНІДО «Шлях до досягнення всеосяжного і стійкого промислового розвитку» щодо структурних змін та пріоритетності промислового розвитку. Саме промисловість забезпечує інші сектори економіки виробничими технологіями, $\epsilon$ базовою для технологічної модернізації. Експерти та фахівці світового співтовариства наголошували на необхідності повернення урядів країн до питань розвитку промисловості, який $є$ фундаментом для реалізації інноваційних ідей в економіці країни та забезпечення іï конкурентоспроможності [7].

В Україні вже давно на державному рівні задекларовано курс на інноваційну модель економічного розвитку. Разом із тим попри ухвалення низки концепцій i державних цільових програм, обговорення проблем інноваційної та науково-технічної діяльності на парламентському рівні, політичну риторику щодо необхідності структурних змін в економіці на основі інноваційно-інвестиційних проєктів, розвиток високих технологій i наукоємних виробництв, інноваційний потенціал технологічна та інноваційна конкурентоспроможність України є нестійкою, що відображено у міжнародних рейтингах (табл. 1).

За даними Всесвітнього економічного форуму, Україна у 2019 р. втратила дві позиції в Індексі глобальної конкурентоспроможності й посіла 85-е місце зі 141 країни. У 2018 р. наша країна посіла у рей- тингу інновацій найвищу позицію за останні роки 43-є місце серед 126 країн світу, покращивши його порівняно з 2017 р. на сім позицій. Проте у 2019 р. рейтинг України за рівнем розвитку інноваційної сфери знову дещо знизився - 47-е місце зі 129 країн світу. Відповідно до індексу інноваційного розвитку, представленого агентством Bloomberg, Україна кожного року демонструє падіння у міжнародному рейтингу. Так, у 2019 р. вона посіла 53-є місце серед 60 досліджуваних держав, у 2020 р. - 56-е місце, опустившись на три сходинки. Найменше балів наша країна отримала за сферу інтенсивної високотехнологічності та за активність патентної діяльності. Європейське інноваційне табло дає змогу порівнювати інноваційний потенціал національних економік країн - членів СС і країн, що мають на меті приєднатися до ЄС. Дані табл. 1 вказують на те, що Україна за Свропейським інноваційним табло знаходиться на рівні європейських аутсайдерів з інновацій та, відповідно до методики, є «повільним новатором».

\section{Таблиця 1 - Україна у глобальному вимірі індикаторів інноваційного розвитку}

\begin{tabular}{|l|c|c|c|c|c|}
\hline \multirow{2}{*}{ Міжнародні індекси } & \multicolumn{5}{|c|}{ Роки } \\
\cline { 2 - 6 } & $\mathbf{2 0 1 5}$ & $\mathbf{2 0 1 6}$ & $\mathbf{2 0 1 7}$ & $\mathbf{2 0 1 8}$ & $\mathbf{2 0 1 9}$ \\
\hline $\begin{array}{l}\text { Глобальний індекс } \\
\text { конкурентоспроможності }\end{array}$ & 79 & 85 & 81 & 83 & 85 \\
\hline $\begin{array}{l}\text { Глобальний індекс } \\
\text { інновацій }\end{array}$ & 64 & 56 & 50 & 43 & 47 \\
\hline $\begin{array}{l}\text { Індекс інноваційного } \\
\text { розвитку агентства } \\
\text { Вlоотьеrg }\end{array}$ & 33 & 41 & 42 & 46 & 53 \\
\hline $\begin{array}{l}\text { Европейське інноваційне } \\
\text { табло }\end{array}$ & 35 & 35 & 35 & 36 & 36 \\
\hline
\end{tabular}

Джерело: складено за [3; 6; 13; 15; 17$]$

Для виправлення ситуації необхідно сприяти розвитку видів економічної діяльності вищих технологічних укладів, перейти від ресурсної до інноваційної моделі економіки. Це можливо за умови адекватності промисловості науково-технічним досягненням постіндустріального суспільства. У Стратегії розвитку сфери інноваційної діяльності на період до 2030 р. зазначається, що «промисловість (України. - Авт.) зможе бути рушієм прискорення економічного розвитку та якісних змін у структурі економіки лише після суттєвої модернізації, виправлення ситуації зі зношеністю основних засобів та впровадження новацій і переходу до виробництва конкурентоспроможних продуктів із високою часткою доданої вартості» [14]. При цьому необхідно враховувати особливу роль переробної промисловості у забезпеченні інноваційної моделі національної економіки. «Культивуючи переробну промисловість, країни заохочували вигідний тип економічної діяльності», - наголошує Е. Райнерт [11, с. 121].

За результатами досліджень експертів переробна промисловість за допомогою міжгалузевих взаємодій формує умови інноваційного розвитку, виступає драйвером економічного зростання за умови, якщо структура iї виробництва матиме такий вигляд: високотехнологічні - 19\%, середньотехнологічні високого рівня - 28\%, середньотехнологічні низького рівня $21 \%$, низькотехнологічні - 32\% [18]. 
Отже, у рамках інноваційної моделі розвитку економіки України слід передбачити інституційні механізми, які сприятимуть формуванню зазначеної вище структури виробництва переробної промисловості. Для того щоб ці механізми були ефективні, необхідно проаналізувати сформовану сьогодні технологічну структуру переробної промисловості України.

У загальному обсязі промислового виробництва України переробна промисловість займає майже 65,0\%. У структурі ВВП частка переробної промисловості демонструє тенденцію до зниження: у 2010 р. - 13,2\%, у 2018 р. - 11,6\%, у 2019 р. - 10,8\%. [5]. Це свідчить про структурне спрощення економіки, що недостатньо для виконання функції драйвера економічного зростання економіки України. Для порівняння: у 2018 р. частка переробної промисловості у ВВП Польщі становила $17,0 \%$, Туреччини - 19,0\%, Словаччини - 20,0\% [2].

Якісною характеристикою переробної промисловості є їі технологічна структура. Згідно з класифікацією Євростату, промислові виробництва за рівнем технологічності поділяються на чотири групи: високотехнологічні, середньо-високотехнологічні, середньо-низькотехнологічні та низькотехнологічні. Класифікація виробництв здійснюється відповідно до двох критеріїв: рівня технологомісткості (визначається співвідношенням витрат на дослідження і розробки до доданої вартості) та частки персоналу 3 вищою освітою. Відзначимо, що в межах даного дослідження проведено аналіз технологічної структури переробної промисловості України згідно 3 класифікацією Євростату.

Базовим критерієм для розподілу видів економічної діяльності за рівнем технологічності є частка витрат на науково-дослідні і дослідно-конструкторські роботи у собівартості продукції. Для високотехнологічних виробництв ця частка перевищує $5 \%$, для середньотехнологічних виробництв перебуває у межах 3-5\%, для виробництв, які використовують низькі технології, ця частка відповідає 1-3\% наукових витрат у собівартості. Додатковими ознаками високотехнологічних виробництв $€$ використання проміжних високотехнологічних видів сировини, матеріалів, комплектуючих для виробництва кінцевої продукції підприємства; випуск проміжної високотехнологічної продукції, котра входить до складу кінцевої високотехнологічної продукції, конкурентоспроможної на зовнішніх ринках; інвестування у техніко-технологічне переозброєння; отримання підприємством у компетентних органах 3 охорони прав інтелектуальної власності охоронних документів на об'єкти інтелектуальної власності; наявність у підприємства міжнародних сертифікатів [1, с. 58].

Високотехнологічний сектор України $є$ меншим, аніж у більшості країн, виробляє 0,5\% ВВП та надає роботу $0,5 \%$ зайнятих осіб. У цьому секторі функціонує лише 4,0\% промислових підприємств (189 у 2017 р.). Проте він є найбільш інтенсивним у виробництві продукції та здійсненні інноваційної діяльності [13, с. 19].

До високотехнологічного сектору, згідно $з$ класифікацією Євростату, відносяться такі види економічної діяльності: 1) виробництво основних фармацевтичних продуктів і препаратів; 2) виробництво комп'ютерів, електронної та оптичної продукції; 3) виробництво повітряних і космічних літальних апаратів, супутнього устаткування. За цими видами діяльності проведено аналіз структурних складників високотехнологічного сектору переробної промисловості України, використовуючи дані Державної служби статистики про реалізацію промислової продукції діяльності за 2015-2020 рр. (табл. 2).

Як видно 3 табл. 2, виробництво фармацевтичних продуктів і препаратів займає першу позицію, хоча його внесок у структуру переробної промисловості доволі скромний - 2,55\% у 2020 р. Стан фармацевтичної галузі, рівень розвитку біотехнології порівняно зі світовим в Україні є невисоким. Так, частка вітчизняного виробництва на ринку імунобіотехнологічних препаратів становить лише 9\%. На українському ринку лікарських засобів частка продукції закордонних фірм становить понад 70\% [16].

Друге місце займає виробництво повітряних і космічних літальних апаратів, супутнього устаткування. Цей вид діяльності демонструє нестабільну динаміку. Найбільша частка була у 2015 р. - 1,59\%, найменша у 2019 р. - 0,88\%. У 2020 р. повітряних і космічних літальних апаратів, супутнього устаткування було реалізовано на 457,5 млн грн більше, ніж у 2019 р., що становило $0,91 \%$ до загального обсягу реалізованої продукції переробної промисловості. Зазначимо, що потреби України у цивільних літаках і вертольотах переважно задовольняються за рахунок імпорту. Урятувати авіаційну промисловість України може велике серійне замовлення. У цьому контексті важливим $\epsilon$ підписання Меморандуму за участю Президента України між Міністерством оборони та ДП «Антонов» про співпрацю щодо будівництва літаків для потреб Збройних сил України. На першому етапі йдеться про три нові військово-транспортні літаки Ан-178, які отримають Збройні сили України [9].

Таблиця 2 - Структура високотехнологічного сектору переробної промисловості України, \%

\begin{tabular}{|l|c|c|c|c|c|c|c|}
\hline \multicolumn{1}{|c|}{ Види економічної діяльності } & \multicolumn{2}{c|}{ Код за } \\
КВЕД-2010 & $\mathbf{2 0 1 5}$ & $\mathbf{2 0 1 6}$ & $\mathbf{2 0 1 7}$ & $\mathbf{2 0 1 8}$ & $\mathbf{2 0 1 9}$ & $\mathbf{2 0 2 0}$ \\
\hline Переробна промисловість, усього & С & 100,0 & 100,0 & 100,0 & 100,0 & 100,0 & 100,0 \\
\hline Високотехнологічні види діяльності, у тому числі: & $21+26+30.3$ & 4,23 & 4,05 & 4,14 & 3,98 & 3,97 & 4,23 \\
\hline $\begin{array}{l}\text { Виробництво основних фармацевтичних продуктів і } \\
\text { препаратів }\end{array}$ & 21 & 1,94 & 2,20 & 2,07 & 2,09 & 2,28 & 2,55 \\
\hline $\begin{array}{l}\text { Виробництво комп’ютерів, електронної та оптичної } \\
\text { продукції }\end{array}$ & 26 & 0,70 & 0,85 & 0,76 & 0,80 & 0,81 & 0,77 \\
\hline $\begin{array}{l}\text { Виробництво повітряних і космічних літальних } \\
\text { апаратів, супутнього устаткування }\end{array}$ & 30.3 & 1,59 & 1,00 & 1,31 & 1,09 & 0,88 & 0,91 \\
\hline
\end{tabular}

Джерело: складено за [8] 
На третьому місці - виробництво комп'ютерів, електронної та оптичної продукції - 0,77\% у 2020 р. Повноцінне виробництво побутової та промислової електронної та оптичної продукції практично відсутнє, а існуючі підприємства фактично займаються складанням готової продукції з імпортних комплектуючих. Виробництво промислової електроніки та оптики спрямоване на задоволення попиту в оборонно-промисловому комплексі, забезпечення потреб вітчизняних підприємств, тому залежить від стану вітчизняного промислового виробництва.

Отже, частка високотехнологічних видів діяльності у загальному обсязі реалізованої продукції переробної промисловості є незначною і становила 4,23\% у 2020 р., що свідчить про фіксацію технологічного відставання промисловості України.

У середньо-високотехнологічному секторі (табл. 3) провідні позиції займає виробництво: 1) хімічних речовин і хімічної продукції; 2) інших транспортних засобів (без будування суден і човнів та виробництва повітряних і космічних літальних апаратів, супутнього устаткування); 3) машин і устаткування. Разом вони становлять понад 70\% цього сектору переробної промисловості.

Слід відзначити зменшення внеску в загальний обсяг продукції переробної промисловості хімічного виробництва - 3 6,12\% у 2015 р. до 4,41\% у 2020 р. Частково це пов'язано з недостатнім субсидіюванням виробництва хімічної продукції $(0,2 \%$ від обсягу ство- реної ними валової доданої вартості), відтермінуванням уведення антидемпінгових імпортних мит для поставок із РФ та військовими діями на Сході України. Зокрема, внаслідок військових дій було пошкоджено виробничу інфраструктуру Донецького казенного заводу хімічних виробів, горлівського ПрАТ «Концерн Стирол», ПАТ «Стаханівський завод технічного вуглецю» тощо [10, с. 50].

Частка виробництва машин і устаткування у загальному обсязі переробної промисловості зменшувалася з 3,9\% у 2016 р. до $1,87 \%$ у 2019 р. У 2020 р. внесок галузі збільшився у два рази і становив 3,76\%. Можна також констатувати відносно стабільний і невисокий внесок виробництв інших транспортних засобів - 2,58\% у 2020 р. У загальному обсязі продукції переробної промисловості України частка виробництв середньо-високотехнологічного сектору $\epsilon$ незначною і становить 14-15\%. Відзначимо, що продукція цього сектору затребувана практично всіма галузями країни, попит яких задовольняється за рахунок імпорту на рівні $80 \%$ [10, с. 11$]$.

Отже, технологічна структура середньо-високотехнологічного сектору закладає залежність від імпорту продукції даного класу вітчизняної економіки.

Провідним технологічним сектором переробної промисловості економіки України є середньотехнологічні виробництва низького рівня, на які припадає майже 40\% реалізованої продукції (табл. 4). Причому половину реалізованої продукції забезпечує металур-

Таблиця 3 - Структура середньо-високотехнологічного сектору переробної промисловості України, \%

\begin{tabular}{|l|c|c|c|c|c|c|c|}
\hline \multicolumn{1}{|c|}{ Види економічної діяльності } & \multirow{2}{*}{ Код за КВЕД-2010 } & \multicolumn{5}{c|}{ Роки } \\
\cline { 3 - 7 } & $\mathbf{2 0 1 5}$ & $\mathbf{2 0 1 6}$ & $\mathbf{2 0 1 7}$ & $\mathbf{2 0 1 8}$ & $\mathbf{2 0 1 9}$ & $\mathbf{2 0 2 0}$ \\
\hline Переробна промисловість, усього & С & 100,0 & 100,0 & 100,0 & 100,0 & 100,0 & 100,0 \\
\hline $\begin{array}{l}\text { Середньо-високотехнологічні види діяльності, } \\
\text { у тому числі: }\end{array}$ & $20+27+28+29+30+32.5$ & 15,77 & 14,42 & 14,31 & 14,61 & 7,48 & 14,56 \\
\hline Виробництво хімічних речовин і хімічної продукції & 20 & 6,12 & 4,94 & 4,23 & 4,19 & 2,16 & 4,41 \\
\hline Виробництво електричного устаткування & 27 & 2,11 & 2,13 & 2,07 & 2,24 & 1,03 & 1,96 \\
\hline Виробництво машин і устаткування & 28 & 3,71 & 3,90 & 3,65 & 3,56 & 1,87 & 3,76 \\
\hline $\begin{array}{l}\text { Виробництво автотранспортних засобів, причепів } \\
\text { і напівпричепів }\end{array}$ & 29 & 1,29 & 1,35 & 1,49 & 1,63 & 0,91 & 1,71 \\
\hline Виробництво інших транспортних засобів & 30 & 2,44 & 2,00 & 2,77 & 2,89 & 1,45 & 2,58 \\
\hline $\begin{array}{l}\text { Виробництво медичних і стоматологічних } \\
\text { інструментів і матеріалів }\end{array}$ & 32.5 & 0,10 & 0,10 & 0,10 & 0,10 & 0,06 & 0,14 \\
\hline
\end{tabular}

Джерело: складено за [8]

Таблиця 4 - Структура середньо-низькотехнологічного сектору переробної промисловості України, \%

\begin{tabular}{|l|c|c|c|c|c|c|c|}
\hline \multicolumn{1}{|c|}{ Види економічної діяльності } & \multirow{2}{*}{ Код за КВЕД-2010 } & \multicolumn{5}{c|}{ Роки } \\
\cline { 4 - 8 } & $\mathbf{2 0 1 5}$ & $\mathbf{2 0 1 6}$ & $\mathbf{2 0 1 7}$ & $\mathbf{2 0 1 8}$ & $\mathbf{2 0 1 9}$ & $\mathbf{2 0 2 0}$ \\
\hline Переробна промисловість, усього & $\mathrm{C}$ & 100,0 & 100,0 & 100,0 & 100,0 & 100,0 & 100,0 \\
\hline $\begin{array}{l}\text { Середньо-низькотехнологічні види діяльності, } \\
\text { у тому числі: }\end{array}$ & $19+22+23+24+25+33$ & 40,13 & 41,08 & 42,94 & 43,76 & 31,77 & 38,2 \\
\hline $\begin{array}{l}\text { Виробництво коксу та продуктів } \\
\text { нафтоперероблення }\end{array}$ & 19 & 5,04 & 5,16 & 5,87 & 5,95 & 2,15 & 3,72 \\
\hline Виробництво гумових і пластмасових виробів & 22 & 2,99 & 3,03 & 2,79 & 2,94 & 2,52 & 3,23 \\
\hline $\begin{array}{l}\text { Виробництво іншої неметалевої мінеральної } \\
\text { продукції }\end{array}$ & 23 & 4,46 & 4,90 & 5,03 & 5,11 & 2,73 & 6,48 \\
\hline Металургійне виробництво & 24 & 24,00 & 24,11 & 25,32 & 25,55 & 20,45 & 20,10 \\
\hline Виробництво готових металевих виробів & 25 & 2,35 & 2,52 & 2,61 & 2,79 & 2,41 & 3,07 \\
\hline Ремонт і монтаж машин і устаткування & 33 & 1,29 & 1,36 & 1,32 & 1,42 & 1,51 & 1,60 \\
\hline
\end{tabular}

Джерело: складено за [8] 
гійне виробництво. Експортний потенціал цього сектору переробної промисловості визначається теж продукцією металургійного виробництва.

Починаючи 32014 р. металургійні підприємства України втратили ринок РФ, що значно скоротило експорт багатьох виробів. Урядом було прийнято рішення 32015 р. переорієнтуватися на ринки країн СС, Північної Африки та Близького Сходу. Відміна ввізного мита до СС на металопродукцію пожвавила експорт. Водночас фізично та морально застарілі технології знижують конкурентоспроможність металургійної галузі України [4, с. 14].

У низькотехнологічному секторі переробної промисловості України провідну позицію займає виробництво харчової продукції - майже $70 \%$ загального обсягу виробництва у цьому секторі. Внесок кожної з інших галузей у 10 і більше разів менше. Натомість експортний потенціал галузей низькотехнологічного сектору переробної промисловості визначається лісопильним виробництво та виробництвом олії і тваринних жирів - відповідно 79,0\% і 74,1\% у 2020 р. У цілому виробництва низькотехнологічного сектору переробної промисловості України створюють 40,0\% продукції з тенденцією до зростання - 43,01\% y 2020 p. [8].

Отже, технологічна структура переробної промисловості обмежує іiі можливості бути драйвером інноваційної моделі розвитку економіки України. 80\% вартості відвантаженої продукції переробної промисловості виробляється галузями середньо-низького i низького технологічного рівня. При цьому частка середньо-високотехнологічного та середньо-низькотехнологічного секторів за 2015-2020 рр. зменшилася відповідно з 15,77\% до $14,56 \%$ і 40,13\% до 38,2\%, а низькотехнологічного сектору - збільшилася з 39,08\% до $43,01 \%$. Тобто рух фінансових та матеріальних ресурсів іде по власному низькотехнологічному контуру, який не забезпечує виведення країни на високотехнологічний рівень.

На нашу думку, причиною відставання технологічного розвитку України є іiі інституційна неспро- можність, яка виявляється в низькій ефективності державної науково-технічної та інноваційної політик, а також фактичній відсутності промислової політики. Як зазначають О. Саліхова, Н. Шелудько, функції формування та реалізації промислової політики покладено на Мінекономрозвитку, а інноваційної - на Міністерство освіти і науки. У таких умовах проблематично системно використовувати важелі впливу [12].

Проте основною проблемою $є$ те, що на рівні держави відсутній орган координації промислової політики. Міністерство промислової політики було ліквідоване наприкінці 2011 р., а створені агентства і департаменти не мали ні загальних інституційних можливостей, ні кадрового потенціалу, здатного формувати та здійснювати ефективну державну промислову політику. Утворилася ситуація, що споріднені галузі (наприклад, металургійне виробництво, хімічна промисловості та машинобудування) не можуть узгодити свої подальші дії.

Зараз можна констатувати, що ліквідація профільного міністерства була стратегічною помилкою, яка дає про себе знати втратами промислового потенціалу, виробництв високотехнологічної продукції, які мають конкурентні переваги, зниженням технологічного рівня, примітивізацією виробничої діяльності тощо. Тому одними 3 першочергових завдань інституційних трансформацій є створення профільного міністерства, розроблення стратегії розвитку промисловості України, механізмів ії реалізації шляхом поєднання інструментів промислової, технологічної та інноваційної політик.

Висновки. Забезпечення інноваційної моделі розвитку економіки України можливо за умов підвищення технологічної структури переробної промисловості, збільшення ступеня локалізації ланцюжків доданої вартості у вітчизняному промисловому виробництві, випереджаючого розвитку високотехнологічних і середньо-високотехнологічних виробництв. Координуючим інститутом вирішення цих завдань має бути створений профільний вищий орган державного управління інноваційним розвитком промисловості.

\section{Список використаних джерел:}

1. Високотехнологічна сфера промисловості України: ресурсні можливості розвитку : монографія / І.В. Одотюк та ін. ; за ред. І.В. Одотюка. Київ : Ін-т економіки та прогнозування, 2013. 391 с.

2. Власюк В. Тривожні канікули. Чи уникнемо ідеального шторму? Економічна правда. URL: https://www.epravda.com.ua/ rus/columns/2020/05/6/660195/ (дата звернення: 25.02.2021)

3. Всесвітня організація інтелектуальної власності (BOIB). URL: https:/www.wipo.int/edocs/pubdocs/en/wipo_pub_gii_2019/ ua.pdf (дата звернення: 25.02.2021).

4. Гринько Т.В. Функції логістичної системи в умовах забезпечення конкурентоспроможності підприємств галузі металургії. Економіка та держава. 2016. № 5. С. 12-16.

5. Державна служба статистики : офіційний сайт. URL: http://www.ukrstat.gov.ua/ (дата звернення: 26.02.2021).

6. Інформаційне агентство «Інтерфакс-Україна» : офіційний сайт. URL: https://ua.interfax.com.ua/ (дата звернення: 25.02.2021)

7. Лімська декларація 15. Шляхи до досягнення всеосяжного і стійкого промислового розвитку. Генеральна конферениія ЮНІДО. Лима-Перу, 2-6 грудня 2013 p. URL: http://www.unido.org/fileadmin/user_media_upgrade/Who_we_are/Structure/ Policymaking_Organs/Lima_Declaration_RU_web.pdf (дата звернення: 25.02.2021).

8. Обсяг реалізованої промислової продукції (товарів, послуг) за видами економічної діяльності у 2015-2020 poках. URL: http://www.ukrstat.gov.ua/operativ/operativ2015/pr/orp_rik/orp_rik_u.htm (дата звернення: 25.02.2021).

9. Офіційне Інтернет-представництво Президента України. Вперше за роки незалежності держава замовляє у «Антонова» три нові українські літаки Ан-178, які отримає армія. URL: https://www.president.gov.ua/news/vpershe-za-roki-nezalezhnostiderzhava-zamovlyaye-u-antonova-65845 (дата звернення: 25.02.2021).

10. Переробна промисловість регіонів України: проблеми та перспективи розвитку : монографія / наук. ред. С.О. Іщук. Львів : Інститут регіональних досліджень імені М.I. Долішнього, 2020. 341 с.

11. Райнерт Э. Как богатые страны стали богатыми и почему бедные страны остаются бедными. Москва : Высшая школа экономики, 2008. 384 с. 
12. Саліхова О., Шелудько Н. Сучасні торговельні війни: на порозі нової індустріальної структури світу. Разумков центр. URL: http://razumkov.org.ua/ uploads/article/2019_trade_wars.pdf (дата звернення: 25.02.2021).

13. Стан інноваційної діяльності та діяльності у сфері трансферу технологій в Україні у 2018 році : аналітична довідка / Т.В. Писаренко та ін. Київ : УкрIНТЕI, 2019. 80 с.

14. Стратегія розвитку сфери інноваційної діяльності на період до 2030 року : Розпорядження Кабінету Міністрів України від 10 липня 2019 р. № 526-p. URL: https://zakon.rada.gov.ua/laws/show/526-2019-\%D1\%80\#n12 (дата звернення: 25.02.2021).

15. Українське національне інформаційне агентство «Укрінформ» : офіційний сайт. URL: https://www.ukrinform.ua/ (дата звернення: 25.02.2021).

16. Урядовий комітет під головуванням Степана Кубіва схвалив Стратегію розвитку високотехнологічних індустрій для України до 2025 року. URL: http://www.me. gov.ua/News/Detail?lang=uk-UA\&id=a8590ddc-7f44-49ed-85874127ca3655bd\&title (дата звернення: 25.02.2021).

17. European innovation scoreboard. URL: https://ec.europa.eu/growth/industry/policy/innovation/scoreboards_еn (дата звернення: 25.02.2021).

18. UNIDO. Industrial Development Report. UNIDO. 2020 URL: https://www.unido.org/resources-publications-flagshippublications-industrial-development-report-series/idr2020 (дата звернення: 25.02.2021).

\section{References:}

1. Odotiuk I.V. (2013) Vysokotekhnolohichna sfera promyslovosti Ukrainy: resursni mozhlyvosti rozvytku: monohrafiia [Hightech industry of Ukraine: resource development opportunities]. Kyiv: In-t ekonomiky ta prohnozuvannia. (in Ukrainian)

2. Vlasiuk V. (2020) Tryvozhni kanikuly. Chy unyknemo idealnoho shtormu? [Anxious vacation. Will we avoid the perfect storm?] Ekonomichna pravda. Available at: https://www.epravda.com.ua/rus/columns/2020/05/6/660195/ (accessed 25 February 2021).

3. Vsesvitnia orhanizatsiia intelektualnoi vlasnosti (2019) [World Intellectual Property Organization] Ofitsiinyi sait. Available at: https://www.wipo.int/edocs/pubdocs/en/wipo_pub_gii_2019/ua.pdf(accessed 25 February 2021).

4. Hrynko T.V. (2016) Funktsii lohistychnoi systemy v umovakh zabezpechennia konkurentospromozhnosti pidpryiemstv haluzi metalurhii. [The functions of the logistics system in terms of ensuring the competitiveness of metallurgy enterprises]. Ekonomika ta derzhava, no. 5, pp. 12-16.

5. Derzhavna sluzhba statystyky. Ukrainy (2020) [State Statistics Service]. Available at: http://www.ukrstat.gov.ua/ (accessed 25 February 2021).

6. Informatsiine ahentstvo «Interfaks-Ukraina» (2020) [Interfax-Ukraine News Agency]. Available at: https://ua.interfax.com.ua/ (accessed 25 February 2021).

7. Limska deklaratsiia 15. (2013) Shliakhy do dosiahnennia vseosiazhnoho i stiikoho promyslovoho rozvytku. [Ways to achieve comprehensive and sustainable industrial development]. Heneralna konferentsiia YuNIDO. Lyma-Peru. Ofitsiinyi sait. Available at: http://www.unido.org/fileadmin/user_media_upgrade/Who_we_are/Structure/Policymaking_Organs/Lima_Declaration_RU_web.pdf. (accessed 25 February 2021).

8. Derzhavna sluzhba statystyky Ukrainy (2020) Obsiah realizovanoi promyslovoi produktsii (tovariv, posluh) za vydamy ekonomichnoi diialnosti u 2015-2020 rokakh [Volume of industrial production (goods, services) by type of economic activity in 2015-2020]. Ofitsiinyi sait. Available at: http://www.ukrstat.gov.ua/operativ/operativ2015/pr/orp_rik_u. htm (accessed 25 February 2021).

9. Ofitsiine internet-predstavnytstvo Prezydenta Ukrainy (2020) Vpershe za roky nezalezhnosti derzhava zamovliaie $u$ «Antonova» try novi ukrainski litaky An-178, yaki otrymaie armiia [For the first time since independence, the state orders three new Ukrainian An-178 aircraft from Antonov, which will be delivered to the army]. Available at: https://www.president.gov.ua/news/vpershe-za-rokinezalezhnosti-derzhava-zam333ovlyaye-u-antonova-65845 (accessed 25 February 2021).

10. Ishchuk S.O. (2020) Pererobna promyslovist rehioniv Ukrainy: problemy ta perspektyvy rozvytku : monohrafiia [Processing industry of the regions of Ukraine: problems and prospects of development]. Lviv: Instytut rehionalnykh doslidzhen imeni M.I. Dolishnoho. (in Ukrainian)

11. Rajnert Je. (2011) Kak bogatye strany stali bogatymi, i pochemu bednye strany ostajutsja bednymi [How rich countries became rich, and why poor countries remain poor]. Moscow: Vysshaja shkola jekonomiki. (in Russian)

12. Salikhova O., Sheludko N. (2019) Suchasni torhovelni viiny: na porozi novoi industrialnoi struktury svitu [Modern trade wars: on the threshold of a new industrial structure of the world]. Razumkov tsentr. Available at: http://razumkov.org.ua/uploads/article/201 9 trade wars.pdf (accessed 25 February 2021).

13. Pysarenko T.V. (2019) Stan innovatsiinoi diialnosti ta diialnosti u sferi transferu tekhnolohii v Ukraini u 2018 rotsi: analitychna dovidka [The state of innovation and technology t9ransfer activities in Ukraine in 2018]. Kyiv: UkrINTEI (in Ukrainian).

14. Rozporiadzhennia Kabinetu Ministriv Ukrainy (2019) Stratehiia rozvytku sfery innovatsiinoi diialnosti na period do $2030 \mathrm{roku}$ [Strategy for the development of innovation in the period up to 2030]. Available at: https://zakon.rada.gov.ua/laws/ show/526-2019-\%D1\%80\#n12 (accessed 25 February 2021).

15. Ukrainske natsionalne informatsiine ahentstvo «Ukrinform» (2020). Available at: https://www.ukrinform.ua (accessed 25 February 2021).

16. Ministerstvo rozvytku ekonomiky, torhivli ta silskoho hospodarstva Ukrainy (2017) Uriadovyi komitet pid holovuvanniam Stepana Kubiva skhvalyv Stratehiiu rozvytku vysokotekhnolohichnykh industrii dlia Ukrainy do 2025 roku [A Government Committee chaired by Stepan Kubiv approved the Strategy for the Development of High-Tech Industries for Ukraine by 2025]. Available at: http://www.me.gov.ua/ News/Detail?lang=uk-UA\&id=a8590ddc-7f44-49edca3655bd\&title (accessed 25 February 2021).

17. European innovation scoreboard (2020). Available at: https://ec.europa.eu/growth/industry/policy/innovation/scoreboards_en (accessed 25 February 2021).

18. UNIDO (2020) Industrial Development Report. Available at: https://www.unido.org/resources-publications-flagshippublications-industrial-development-report-series/idr2020 (accessed 25 February 2021). 
Sokolova Olga

University of the State Fiscal Service of Ukraine

\section{THE ROLE OF TECHNOLOGICAL STRUCTURE OF PROCESSING INDUSTRY IN PROVIDING AN INNOVATIVE MODEL OF UKRAINIAN ECONOMY DEVELOPMENT}

The article substantiates the special role of the processing industry in providing an innovative model of the national economy. It is established that modern industry, especially its high-tech sector, is a generator of scientific and technological progress and innovation in the economy. It is determined that among the most influential and at the same time problematic parts of the industry of Ukraine is the technological structure of the processing industry. The purpose of the article is to analyze the current state of the technological structure of the processing industry of Ukraine and substantiate its role in providing an innovative model of economic development of Ukraine, to develop practical recommendations. The study used such methods as comparative and statistical analysis (in the analysis of structural components of the processing industry), critical analysis (in the study of problems that inhibit the innovative development of Ukraine's economy), systematization and generalization (in formulating proposals to improve technological structure). The research results, conclusions and recommendations are substantiated by an integrated approach. It is proved that the implementation of the innovation strategy makes special demands on the industry, its adequacy to scientific and technical achievements of post-industrial society. It is determined that the qualitative characteristic of the processing industry is its technological structure. The analysis of four sectors of the technological structure of the processing industry by the level of manufacturability - high-tech, medium-high-tech, medium-low-tech and low-tech. The analysis of the structural components of the manufacturing sectors was carried out by type of economic activity according to the Eurostat classification. It is emphasized that in order to increase the technological structure of the processing industry it is necessary to ensure the advanced development of high-tech and medium-high-tech industries. It is established that the reason for the lag in the technological development of Ukraine is its institutional failure. It is proposed to create a specialized supreme body of state management of innovative development of industry.

Key words: technological structure, industry, processing industry, high-tech production, innovative development model.

JEL classification: $\mathrm{O} 23, \mathrm{O} 32, \mathrm{O} 38$ 